\title{
Effect of natural honey on lowering lipid profile
}

\author{
Mohammed K. Alkhalifah, MD, Khaled A. Alabduljabbar, MD, Abdullah H. Alkhenizan, MD, CCFP.
}

\begin{abstract}

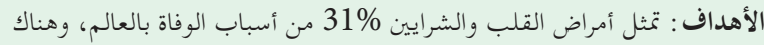

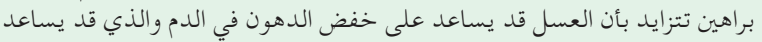

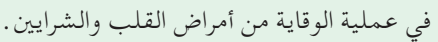

المنهجية : تم البحث في مايو 2020 لكل الدراسات المنضبطة المعشّاة في المصادر

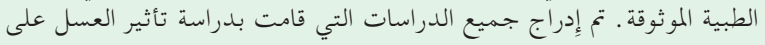

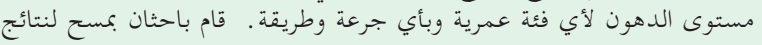

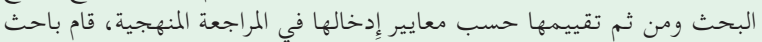

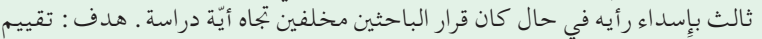

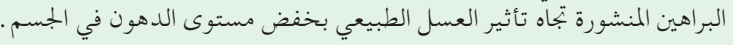

النتائج: تم استخراج V دراسات بواقع 370 مشارك تم قبولهمه، ومن التحليل

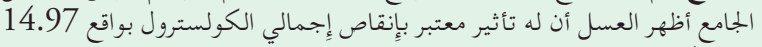

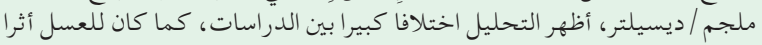

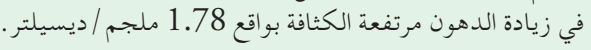

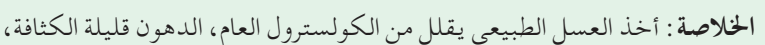

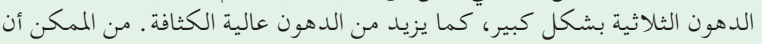

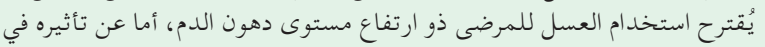

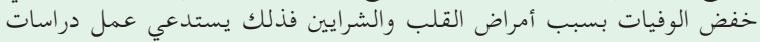

Objectives: To evaluate the available evidence of natural honey and its effect on improving lipid profiles among the adult population.

Methods: The following databases were searched in May 2020 for randomized controlled trials (RCTs) and crossover studies without any restrictions in language, publication year, or status: CENTRAL, Embase Elsevier, ClinicalTrials.gov, MEDLINE, the WHO International Clinical Trials Registry Platform, and Google Scholar. We included all RCTs and crossover studies that studied the effect of natural honey on improving lipid levels in individuals at any age, for any dose and duration. Trials investigated the intake of honey alone or honey dissolved in water. The comparison groups were no intervention or placebo. Two independent reviewers screened and evaluated the included trials. The third reviewer was involved in resolving any disagreement. Our aim was to evaluate the evidence available regarding the effect of natural honey in improving lipid profile.
Results: Seven trials with 370 participants fitted the inclusion criteria. Pooled analysis showed, honey was found to reduce total cholesterol levels with statistical significance (mean difference [MD]: $-14.97 \mathrm{mg} / \mathrm{dl}$, 95\% CI: 19.61 to -10.32). Honey was associated with a statistically significant increase in high-density lipoprotein (HDL) levels (MD: $1.78 \mathrm{mg} / \mathrm{dl}, 95 \%$ CI: 0.68 to 2.88). There was a statistically significant LDL reduction level (MD: $18.99 \mathrm{mg} / \mathrm{dl}, 95 \%$ CI: -22.79 to -15.20 ). Finally, honey was found to lower triglyceride levels significantly (MD: $9.68 \mathrm{mg} / \mathrm{dl}$, 95\% CI: -15.56 to -3.80 ).

Conclusions: Total cholesterol was significantly reduced with the use of natural honey intake, as well as lowdensity lipoprotein (LDL), and triglycerides. Highdensity lipoprotein showed significant increment. Small quantity of honey can be recommended for patients with dyslipidemia. The impact on clinical outcomes such as cardiovascular mortality and morbidity needs to be evaluated in large studies.

PROSPERO REG. NO. CRD: 42020130741

Keywords: honey, systematic review, meta-analysis, dyslipidemia, lipid, CVD.

Saudi Med J 2021; Vol. 42 (5): 473-480

doi: 10.15537/smj.2021.42.5.20200664

From the Department of Family Medicine \& Polyclinics, King Faisal Specialist Hospital and Research Centre, Riyadh, Kingdom of Saudi Arabia.

Received 3rd December 2020. Accepted 22nd March 2021.

Address correspondence and reprint request to: Dr. Abdullah $H$. Alkhenizan, Department of Family Medicine \& Polyclinics, King Faisal Specialist Hospital and Research Centre, Riyadh, Kingdom of Saudi Arabia.E-mail:akhenizan@kfshrc.edu.sa

ORCID ID: http://orcid.org/0000-0002-0269-5200

$T$ he rate of CVD mortality represents $31 \%$ of total global deaths. ${ }^{1}$ A healthy endothelium has vasodilatory, anti-inflammatory, and anti-atherogenic effects. When the endothelium function is impaired, platelet activation, thrombogenesis, cytokine adhesion, and inflammation will be dysregulated. This results in 
atherosclerosis formation by plaques. Dyslipidemia, diabetes, and hypertension are well-known contributors to the pathophysiology and promote further damage to the endothelium. ${ }^{2,3}$ Complete blockage or restricted flow caused by narrowed arteries, for which atherosclerosis is responsible, limits the amount of oxygen delivered to tissue and organs. In addition to the natural aging process, other factors such as high cholesterol, smoking, hypertension, torpid lifestyle and obesity may accelerate the hardening and narrowing of the arteries. ${ }^{4}$

Honey contains a heterogeneous class of chemical compounds that are defined as polyphenols. 5 These are further divided into 4 subcategories. Two of them in which honey is rich in non-flavonoids (phenolic acids) and flavonoids. ${ }^{6}$ These substances are carrying antioxidant activities. They scavenge free radical. They form less toxic and stable molecules. ${ }^{5}$ Nevertheless, various in and ex-vivo studies evinced anticancer, antifungal, antimicrobial, antidiabetic, and antiviral activity of honey. Its safeguarding actions on gastrointestinal, cardiovascular, respiratory, and nervous systems has also been evident. ${ }^{7,8}$ Multiple mechanisms can accomplish the amelioration of CVD, for example, improving coronary vasodilatation, improving endothelial function, inhibiting platelet aggregation, reducing lipoprotein (LDL) oxidation, reducing inflammatory response, decreasing oxidative stress, and providing antioxidant protection. ${ }^{9-15}$

Evidence from observational and interventional studies is inconclusive regarding the effect of honey consumption on clinical cardiovascular risk factors such as lipid profile. In this systematic review and metaanalysis we aim to evaluate the available evidence of natural honey and its effect on improving lipid profiles among the adult population.

Methods. The following databases were searched in May 2020 for the word 'honey' for randomized controlled trials (RCTs) and crossover studies without any restrictions to language, publication year, or status: the Cochrane Central Register of Controlled Trials (CENTRAL), Embase, and MEDLINE. We also screened all reference lists. We have contacted the authors when we needed extra information.

We included all RCTs and crossover studies that studied the effect of natural honey on lipid profile in

Disclosure. Authors have no conflict of interests, and the work was not supported or funded by any drug company. participants without or with chronic illnesses at any age, for any dose and duration, in an outpatient setting. The trials investigated the intake of natural honey alone or honey dissolved in water. The comparison groups were no intervention or placebo. The outcome of interest was change in lipid profile, including total cholesterol, LDL, HDL, and triglycerides. To avoid confounding, we excluded trials involving multifactorial lifestyle interventions or honey mixed with anything in the control group.

We imposed no restrictions on type, dose, or formulation. We included the controls who received either placebo or no intervention. We included studies of any duration ranging from 4 weeks to 12 weeks.

Two reviewers independently evaluated the risk of bias (RoB) of all studies employing the Cochrane Collaboration's tool for assessing RoB. The reviewers screened the abstracts for inclusion criteria. Included articles were fully evaluated for the final inclusion decision. The third reviewer was involved in resolving any disagreement. The outcome measurements were descriptive measures reported as the difference in mean pre- and post-honey treatment and SD.

The RevMan 5.3 statistical package was utilized to pool the results of all included studies.

$\mathrm{I}^{2}$ test was used to assess the heterogeneity and considered substantial when it was $\geq 50 \%$. We estimated the weight of treatment effect by using random effect model to ensure the robustness of the results whenever there was substantial heterogeneity amongst studies. Potential sources of heterogeneity of treatment effect were explored. The confidence interval was set at $95 \%$ and a 2 -tailed $p$-value of $\geq 0.05$.

Results. Our search generated 1569 hits, and 497 were removed as duplicates. The titles and abstracts of 1072 were screened, 1056 were excluded, and 16 papers were identified for final exclusion or inclusion. Of them, we included 7 RCTs which met the criteria for inclusion. A diagram of the study flow details is given in Figure 1. Table 1 elucidates the reason of excluded studies. The reasons for the exclusions were mainly short-term trial (less than 4 weeks), no control group, using honey in all trial arms, or an intervention that was not pure honey.

Table 2 presented the characteristics of all included studies and information about the duration, intervention, and the number of participants in each included study. The RoB is summarized in Figures $2 \& 3$.

Three hundred and seventy participants out of 7 trials with were included. Total number of the experimental group was 197 participants, and 173 
Effect of natural honey on lipid profile ... Alkhalifah et al

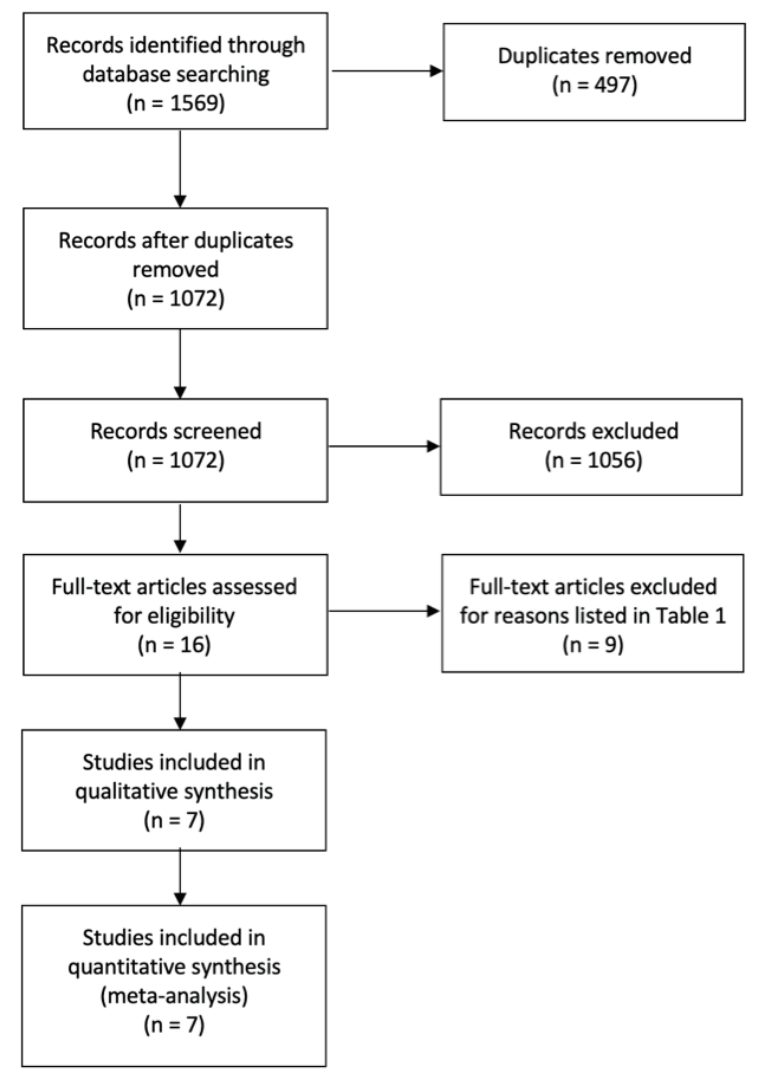

Figure 1 - Characteristics of excluded studies.

participants were in the control group. Approximately $20 \%$ of the participants were females. The duration of the studies ranged between 4 and 12 weeks. One study by Abdulrahman et $\mathrm{al}^{16}$ included 20 pediatric participants with an age range of 4-18 years. One study was a randomized crossover clinical trial. The mortality and clinical events were not measured, as they were not included in the studies' objectives.

From the pooled analysis, statistically speaking, honey has significantly reduced total cholesterol levels (mean difference [MD] - $14.97 \mathrm{mg} / \mathrm{dl}$; 95\% confidence interval $[\mathrm{CI}]-19.61$ to -10.32$)$; test for heterogeneity: $\mathrm{I}^{2}=44 \%$ (Figure 4). Intriguingly, honey has a statistical significance in raising the HDL levels when compared to control (MD $1.78 \mathrm{mg} / \mathrm{dl}$; 95\% CI 0.68 to 2.88 ); test for heterogeneity: $I^{2}=84 \%$ (Figure 5). For LDL levels, the heterogeneity significantly existed between studies $\left(\mathrm{I}^{2}=88 \%\right)$, and there was a statistically significant decrease in the LDL levels (MD -18.99 mg/dl; 95\% CI -22.79 to -15.20) (Figure 6). Finally, honey lowered the level of triglyceride significantly (MD $-9.68 \mathrm{mg} /$
Table 1 - Characteristics of excluded studies.

\begin{tabular}{|c|c|c|}
\hline Study & Year & Reason for exclusion \\
\hline Alemam et $\mathrm{al}^{23}$ & 2019 & No control group \\
\hline Al-Waili ${ }^{24}$ & 2004 & No control group \\
\hline Arani et $a^{25}$ & 2018 & $\begin{array}{l}\text { Inappropriate comparator intervention } \\
\text { (honey in both arms) }\end{array}$ \\
\hline Bekkaye et $\mathrm{al}^{26}$ & 2016 & No control group \\
\hline Bhatti et $\mathrm{al}^{27}$ & 2016 & No control group \\
\hline $\begin{array}{l}\text { Derakhshandeh- } \\
\text { Rishehri et } \mathrm{a}^{28}\end{array}$ & 2014 & No pure honey \\
\hline Despland et $\mathrm{al}^{29}$ & 2017 & $\begin{array}{l}\text { Short-term trial (the follow-up period } \\
\text { was eight days) }\end{array}$ \\
\hline Erejuwa et $\mathrm{al}^{30}$ & 2019 & Still on-going study \\
\hline Whitfield et $\mathrm{al}^{31}$ & 2016 & $\begin{array}{l}\text { Inappropriate comparator intervention } \\
\text { (honey in all arms) }\end{array}$ \\
\hline
\end{tabular}

dl; $95 \%$ CI -15.56 to -3.80$)$; test for heterogeneity: $\mathrm{I}^{2}=88 \%$ (Figure 7 ).

Discussion. Our review, interestingly, revealed that the consumption of natural honey produced a statistically significant decrement in triglycerides, LDL, and total cholesterol. The review also showed that honey increased HDL significantly.

This review included adult participants and one study of the pediatric age group. All participants did not have the same baseline lipid profile. Both genders were included, with a majority of men over women. The effect of duration or "dose" of the intervention was not included in our results. Furthermore, because of the variation among the included studies of natural honey dosage consumed, we could not draw a conclusion about how many grams would be required to improve the lipid profile.

Some RoB was detected in the studies included in our review, it was mainly blinding bias, and therefore, cautious treatment of the results is mandatory. In half of the included trials, the methods of randomization were assessed to have low risk, whereas in all 7 trials the allocation concealment details were not declared. All studies demonstrated low RoB related to incomplete outcome. Selective outcome reporting bias was low in all studies. Judging the risk of other biases was not possible due to information insufficiency for all studies.

Due to the variation in doses, durations and forms of intervention in the included trials, small study bias is a risk in our review. Because of limited included trials, the publication bias was not tested in funnel plots. None 
Table 2 - Characteristics of Included Studies.

\begin{tabular}{|c|c|c|c|c|}
\hline Study & Year & Duration & Participants & Interventions \\
\hline Abdulrhman et $\mathrm{al}^{16}$ & 2013 & $\begin{array}{l}\text { Two } 12 \\
\text { weeks } \\
\text { (crossover) }\end{array}$ & $\begin{array}{c}20 \text { pediatric patients of both } \\
\text { sexes ( } \mathrm{F}: \mathrm{M}=1: 1) \text {, aged } 4-18 \\
\text { years, with insulin-dependent } \\
\text { diabetes. }\end{array}$ & $\begin{array}{l}0.5 \mathrm{~mL} \text { of honey per } \mathrm{kg} \text { body weight daily compared } \\
\text { with control group, who did not receive anything. }\end{array}$ \\
\hline Bahrami et al ${ }^{32}$ & 2009 & 8 weeks & $\begin{array}{l}48 \text { patients ( } 13 \text { men and } 35 \\
\text { women), with type II diabetes. }\end{array}$ & $\begin{array}{l}\text { Natural honey with doses indetails ( } 1^{\text {st }} 2 \text { weeks, } \\
1 \mathrm{~g} / \mathrm{kg} / \mathrm{day} ; 2^{\text {nd }} 2 \text { weeks, } 1.5 \mathrm{~g} / \mathrm{kg} / \text { day; } 3^{\text {rd }} 2 \text { weeks, } \\
2 \mathrm{~g} / \mathrm{kg} / \text { day; and the last } 2 \text { weeks, } 2.5 \mathrm{~g} / \mathrm{kg} / \text { day }) \\
\text { compared with no treatment for the control group. }\end{array}$ \\
\hline Majid et $\mathrm{al}^{33}$ & 2013 & 4 weeks & $\begin{array}{l}70 \text { healthy young males. } 7 \\
\text { participants dropped out } \\
\text { because of lifestyle changes } \\
\text { during the study. }\end{array}$ & $\begin{array}{l}70 \mathrm{~g} \text { of honey taken daily for } 4 \text { weeks period; } \\
\text { control group was kept on the same diet as that of } \\
\text { experimental group except honey. }\end{array}$ \\
\hline Münstedt et $\mathrm{al}^{34}$ & 2019 & 4 weeks & $\begin{array}{l}60 \text { male patients with } \\
\text { hyperlipidemia. }\end{array}$ & $\begin{array}{l}75 \mathrm{~g} \text { of honey compared with } 75 \mathrm{~g} \text { glucose and } \\
\text { fructose solution with an identical content (honey- } \\
\text { comparable sugar solution). }\end{array}$ \\
\hline Rasad et $\mathrm{al}^{35}$ & 2018 & 6 weeks & $\begin{array}{l}60 \text { healthy males, aged } 18-30 \\
\text { years, non-athletic and non- } \\
\text { smoker. }\end{array}$ & $\begin{array}{c}70 \mathrm{~g} \text { natural honey solved in } 250 \mathrm{~mL} \text { tap water } \\
\text { compared with } 70 \mathrm{~g} \text { of sucrose solved in } 250 \mathrm{~mL} \text { tap } \\
\text { water daily. }\end{array}$ \\
\hline Wan Ghazali et $\mathrm{al}^{36}$ & 2015 & 12 weeks & $\begin{array}{l}64 \text { male smokers, aged } 20-50 \\
\text { years. }\end{array}$ & $\begin{array}{l}20 \mathrm{~g} / \text { day of Tualang honey compared with control } \\
\text { group, who did not receive anything. }\end{array}$ \\
\hline Yaghoobi et al ${ }^{17}$ & 2008 & 30 days & $\begin{array}{c}55 \text { overweight or obese subjects, } \\
\text { aged } 20-60 \text { years, } 24 \text { males and } \\
31 \text { females. }\end{array}$ & $\begin{array}{c}70 \mathrm{~g} \text { of honey liquefied in } 250 \mathrm{ml} \text { tap water compared } \\
\text { with } 70 \mathrm{~g} \text { of sucrose dissolved in the same amount of } \\
\text { water daily. }\end{array}$ \\
\hline
\end{tabular}

\section{Random sequence generation (selection bias)}

Allocation concealment (selection bias)

Blinding of participants and personnel (performance bias)

Blinding of outcome assessment (detection bias)

Incomplete outcome data (attrition bias)

Selective reporting (reporting bias)

Other bias
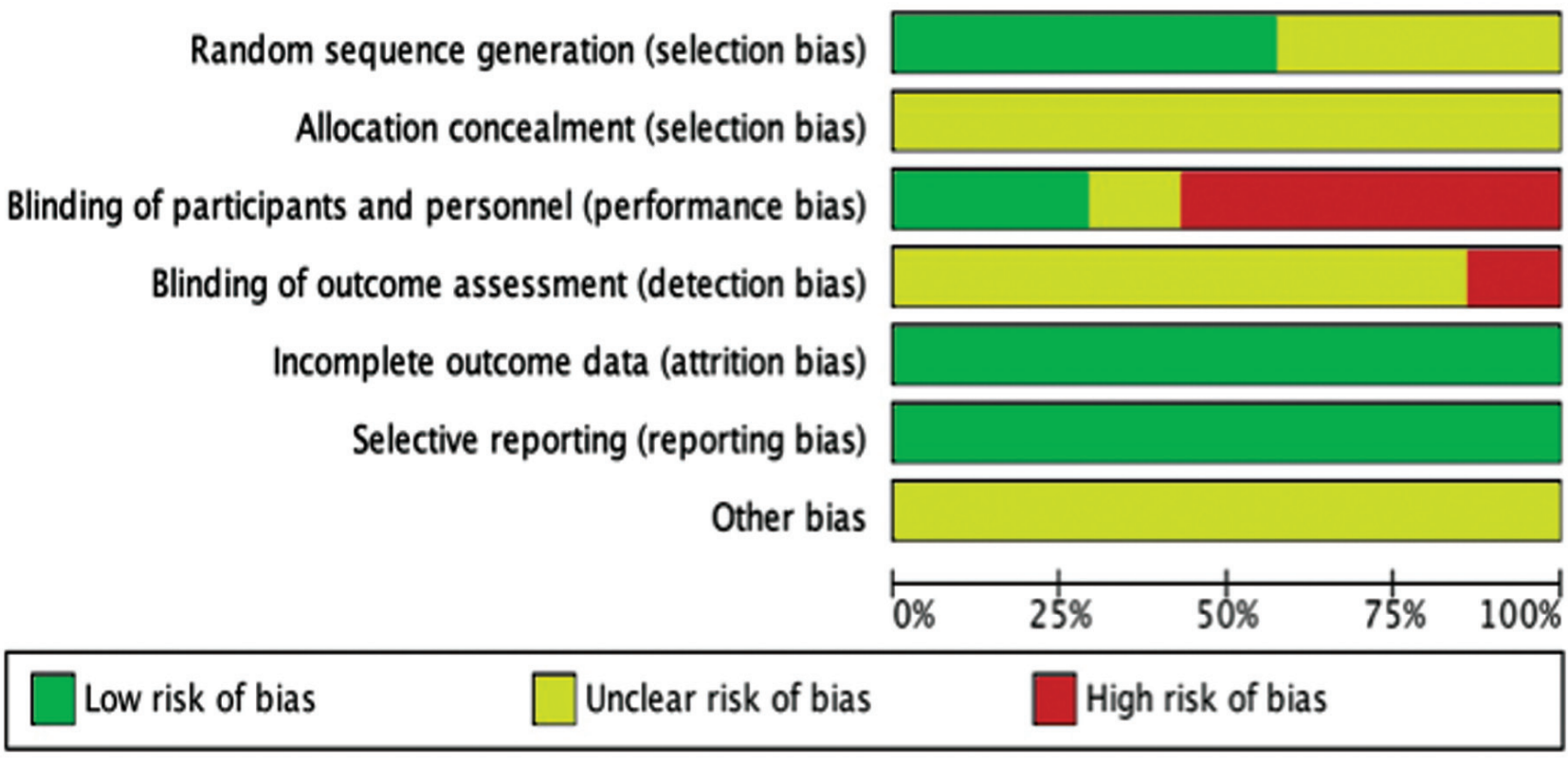

Figure 2 - Risk of bias graph showing the review of authors' judgements regarding each risk-of-bias item presented as percentages across all included studies. 


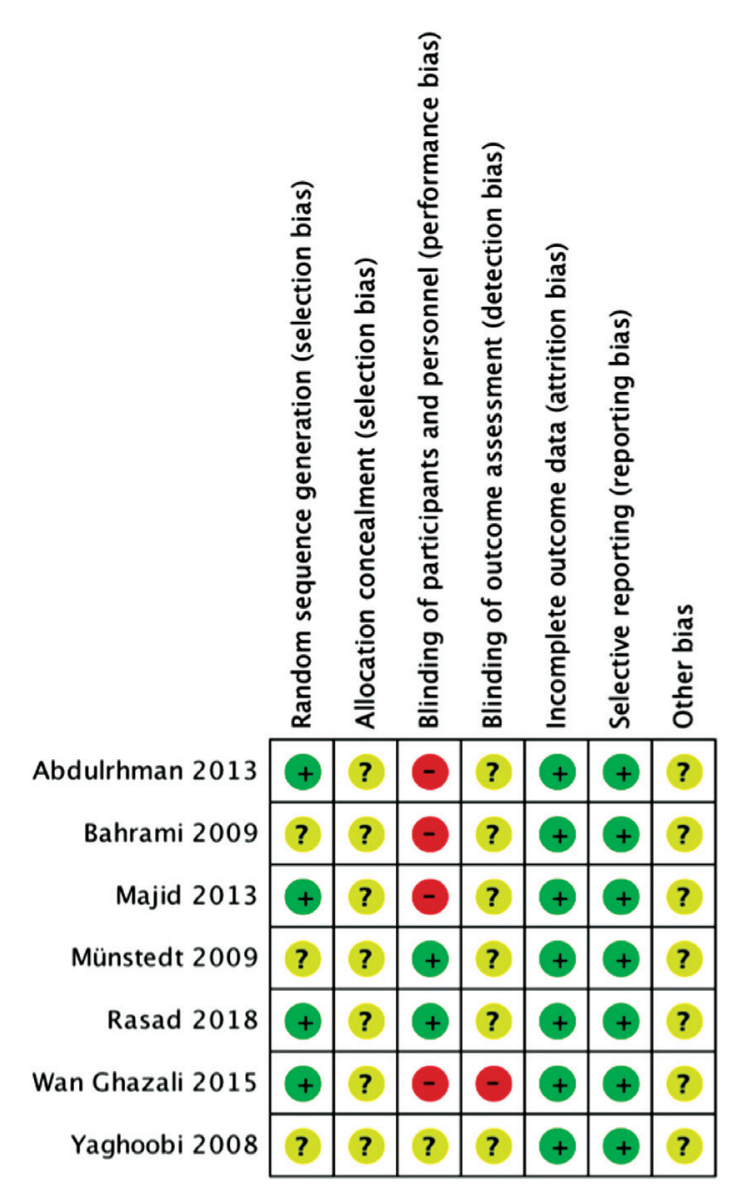

Figure 3 - Risk of bias summary showing the review authors' judgements about each risk-of-bias item for each included study. the less, small trials are mostly not methodologically airtight, are mostly conducted in selected populations, and have been reporting advantageous effects more than larger trials. The results of the review are therefore inconclusive.

Experimental evidence has indicated that the consumption of natural honey may have a beneficial effect on the lipid profile. ${ }^{9,17}$ particular, the literature suggests that the ingestion of natural honey and the reduction in CVD risk are linked, ${ }^{5,6}$ as the flavonoids will prevent the oxidation of low-density lipoprotein, as shown in-vitro, which may take a part in coronary heart disease (CHD) prevention. ${ }^{18}$ Additionally, these antioxidant functions' is to inhibit acyl-CoA cholesterol acyltransferase 2 (ACAT2), up-regulating LDL receptor and activating CYP7A1. Once the receptor is activated (up-regulated), the LDL clearance from the circulation will be more.

One of the suggested mechanisms of how honey changes the lipid profile is by the niacin-like substances' properties. ${ }^{19}$ Sustained niacin release is proven to be the most effective modifier of lipids. ${ }^{20,21}$ Aliphatic compounds, benzene derivatives, norisoprenoids, and maillard reaction products are examples of niacin-like substances found in honey. Another suggested mechanism is that honey acts on the parasympathetic system to abundantly release insulin. ${ }^{22}$

Furthermore, Niacin decreases the mobilization of fatty acid from adipose tissue when taken adequately. This produces rapid and large reduction in the levels of triglycerides. Thus, the liver going to secret smaller

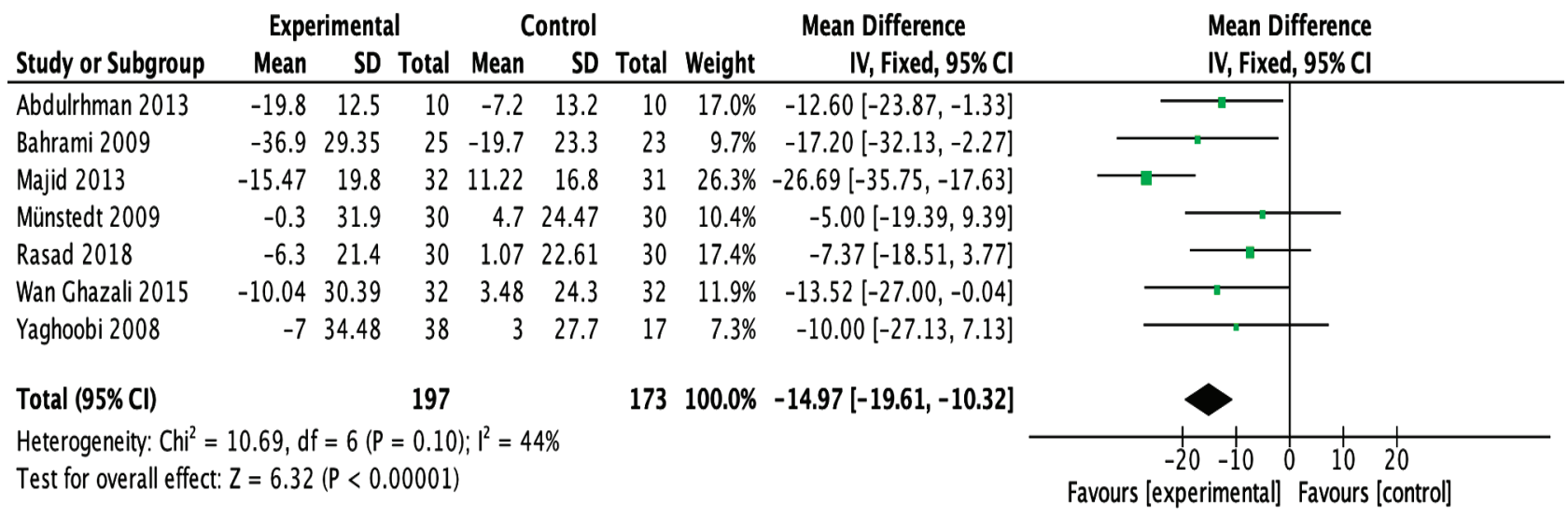

Figure 4 - Forest plot of comparison showing the experimental (honey) versus control groups (outcome 1: total cholesterol). 


\begin{tabular}{|c|c|c|c|c|c|c|c|c|c|c|}
\hline \multirow[b]{2}{*}{ Study or Subgroup } & \multicolumn{3}{|c|}{ Experimental } & \multicolumn{3}{|c|}{ Control } & \multicolumn{2}{|r|}{ Mean Difference } & \multirow{2}{*}{\multicolumn{2}{|c|}{$\begin{array}{l}\text { Mean Difference } \\
\text { IV, Fixed, } 95 \% \mathrm{Cl}\end{array}$}} \\
\hline & Mean & SD & Total & Mean & SD & Total & Weight & IV, Fixed, 95\% Cl & & \\
\hline Abdulrhman 2013 & 9.1 & 5.68 & 10 & -0.9 & 7.55 & 10 & $3.5 \%$ & $10.00[4.14,15.86]$ & & 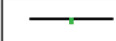 \\
\hline Bahrami 2009 & 6.9 & 9.2 & 25 & 1.1 & 8.53 & 23 & $4.8 \%$ & $5.80[0.78,10.82]$ & & - \\
\hline Majid 2013 & 1.71 & 4.1 & 32 & 0.62 & 2.7 & 31 & $41.4 \%$ & $1.09[-0.62,2.80]$ & & $F$ \\
\hline Münstedt 2009 & -2.8 & 12.2 & 30 & -2.3 & 8.3 & 30 & $4.3 \%$ & $-0.50[-5.78,4.78]$ & . & - \\
\hline Rasad 2018 & 2.94 & 4.67 & 30 & -3.65 & 5.32 & 30 & $18.9 \%$ & $6.59[4.06,9.12]$ & & - \\
\hline Wan Chazali 2015 & -1.93 & 5.28 & 32 & 0.38 & 4.1 & 32 & $22.5 \%$ & $-2.31[-4.63,0.01]$ & $-H_{-1}$ & \\
\hline Yaghoobi 2008 & 2 & 9.16 & 38 & 2 & 9 & 17 & $4.5 \%$ & $0.00[-5.18,5.18]$ & $\longrightarrow$ & - \\
\hline Total $(95 \% \mathrm{Cl})$ & & & 197 & & & 173 & $100.0 \%$ & $1.78[0.68,2.88]$ & & $\downarrow$ \\
\hline $\begin{array}{l}\text { Heterogeneity: } \mathrm{Chi}^{2}= \\
\text { Test for overall effect }\end{array}$ & $\begin{array}{l}37.66, d \\
Z=3.18\end{array}$ & $\begin{array}{l}f=6 \\
8(P=\end{array}$ & $\begin{array}{l}(P<0.0 \\
0.001)\end{array}$ & 00001 & $1=0$ & & & & $\begin{array}{ccc}-20 & -10 & 0 \\
\text { Favours [control] }\end{array}$ & $\begin{array}{l}10 \\
\text { Favours }\end{array}$ \\
\hline
\end{tabular}

Figure 5 - Forest plot of comparison showing the experimental (honey) versus control groups (outcome 2: HDL cholesterol).

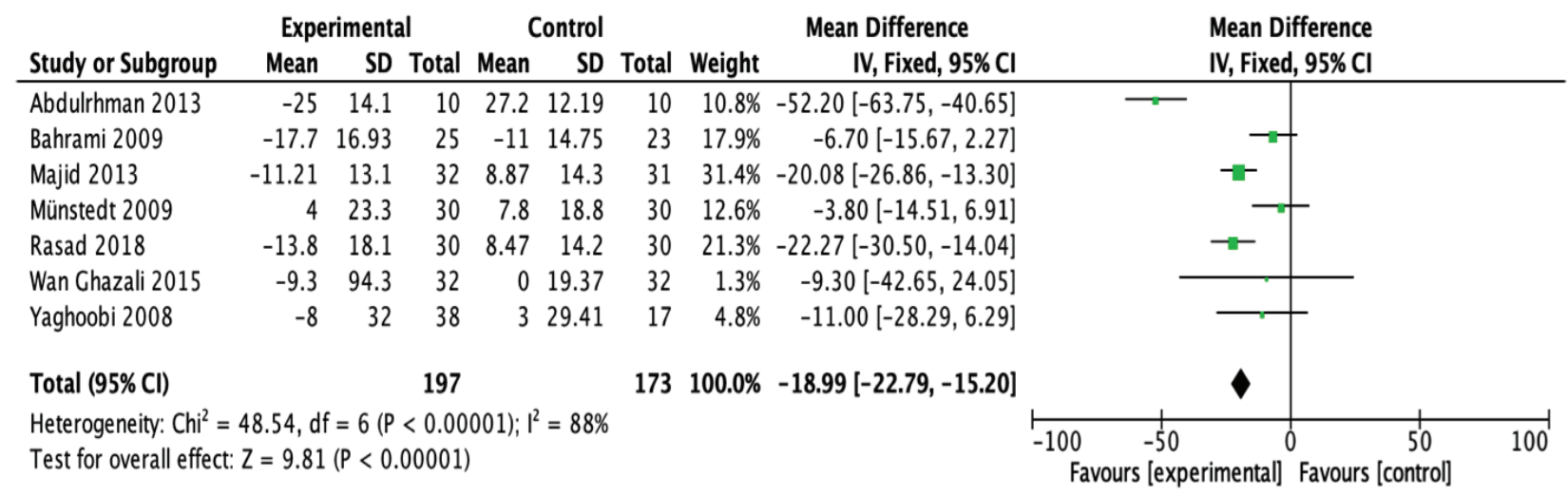

Figure 6 - Forest plot of comparison showing the experimental (honey) versus control groups (outcome 3: LDL cholesterol).

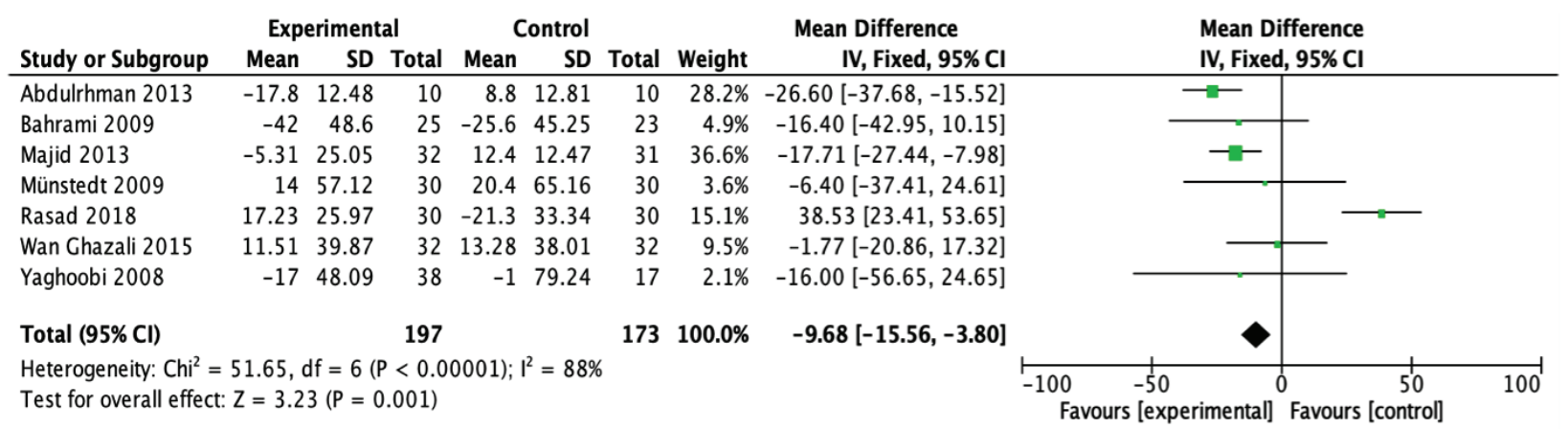

Figure 7 - Forest plot of comparison showing the experimental (honey) versus control groups (outcome 4: triglycerides). 
amount of VLDL with smaller amount of triglycerides. Apolipoprotein B gathers VLDL cholesterol, yet the effect of niacin activity may inhibit its secretion, resulting in less VLDL cholesterol. Triglycerides levels can be reduced as well by the enhancement of VLDL catabolism. ${ }^{20}$

Our comprehensive search across major databases for interventions involving natural honey. When necessary, authors were contacted, and the list of references was screened and reviewed. The well-known systematic review steps starting from screening, inclusion, and exclusion through data extraction were executed by 2 independent reviewers. Entry and analysis of the date were carried out by one reviewer and reviewed by the second one to assure accuracy of the data entered. We decided to limit our review to interventions solely investigating natural honey avoided potential confounding effects. In addition, because of the small number of trials in this review, the methodological quality reporting was considered limited, and in more than half of the included trials, the assessment of risk of bias was unclear.

In conclusion, natural honey in our review expressed a statistically significant reduction in triglycerides, LDL, and total cholesterol. Honey increased HDL significantly. Noteworthy, honey can be recommended for patients with dyslipidemia if consumed in small quantities not more than $75 \mathrm{~g}$ as used by most of the included studies whether alone or dissolved in water. The impact on clinical outcomes such as cardiovascular mortality and morbidity needs to be evaluated in large studies.

Acknowledgment. We acknowledge Scribendi (www.scribendi. com) for English language editing.

\section{References}

1. Cardiovascular diseases (CVDs) [Internet]. World Health Organization; 2017 [cited 2020 May 15]. Available from: https://www.who.int/news-room/fact-sheets/detail/ cardiovascular-diseases-(cvds)

2. American Diabetes Association. Standards of medical care in diabetes-2008. Diabetes Care 2008; 31 Suppl 1: S12-S54.

3. Dokken BB. The pathophysiology of cardiovascular disease and diabetes: beyond blood pressure and lipids. Diabetes Spectr 2008; 21: 160-165.

4. National Health Service. Stroke. [cited 15 May 2020]. Available from: https://www.nhs.uk/conditions/stroke.

5. Cianciosi D, Forbes-Hernández TY, Afrin S, Gasparrini M, Reboredo-Rodriguez P, Manna PP, et al. Phenolic compounds in honey and their associated health benefits: A review. Molecules 2018; 23: E2322.
6. Hossen MS, Ali MY, Jahurul MH, Abdel-Daim MM, Gan SH, Khalil MI. Beneficial roles of honey polyphenols against some human degenerative diseases: A review. Pharmacol Rep 2017; 69: 1194-1205.

7. Alvarez-Suarez JM, Giampieri F, Battino M. Honey as a source of dietary antioxidants: structures, bioavailability and evidence of protective effects against human chronic diseases. Curr Med Chem 2013; 20: 621-638.

8. Alvarez-Suarez JM, Giampieri F, Cordero M, Gasparrini M, Forbes-Hernández TY, Mazzoni L, et al. Activation of AMPK/ Nrf2 signaling by Manuka honey protects human dermal fibroblasts against oxidative damage by improving antioxidant response and mitochondrial function promoting wound healing. J Funct Foods 2016; 25: 38-49.

9. Benavente-García O, Castillo J. Update on uses and properties of citrus flavonoids: new findings in anticancer, cardiovascular, and anti-inflammatory activity. J Agric Food Chem 2008; 56: 6185-6205.

10. Heiss C, Kleinbongard P, Dejam A, Perré S, Schroeter H, Sies $\mathrm{H}$, et al. Acute consumption of flavanol-rich cocoa and the reversal of endothelial dysfunction in smokers. J Am Coll Cardiol 2005; 46: 1276-1283.

11. Hussain NH, Sulaiman SA, Hassan II, Kadir AA, Nor NM, Ismail SB, et al. Randomized controlled trial on the effects of tualang honey and hormonal replacement therapy (HRT) on cardiovascular risk factors, hormonal profiles and bone density among postmenopausal women: a pilot study. J Food Res 2012; 1: 171-88.

12. Mathur S, Devaraj S, Grundy SM, Jialal I. Cocoa products decrease low density lipoprotein oxidative susceptibility but do not affect biomarkers of inflammation in humans. J Nutr 2002; 132: 3663-3667.

13. Wan Y, Vinson JA, Etherton TD, Proch J, Lazarus SA, KrisEtherton PM. Effects of cocoa powder and dark chocolate on LDL oxidative susceptibility and prostaglandin concentrations in humans. Am J Clin Nutr 2001; 74: 596-602.

14. Solayman M, Ali Y, Alam F, Islam MA, Alam N, Khalil MI, et al. Polyphenols: potential future arsenals in the treatment of diabetes. Curr Pharm Des 2016; 22: 549-565.

15. Urquiaga I, Leighton F. Plant polyphenol antioxidants and oxidative stress. Biol Res 2000; 33: 55-64.

16. Abdulrhman MM, El-Hefnawy MH, Aly RH, Shatla RH, Mamdouh RM, Mahmoud DM, et al. Metabolic effects of honey in type 1 diabetes mellitus: a randomized crossover pilot study. J Med Food 2013; 16: 66-72.

17. Yaghoobi N, Al-Waili N, Ghayour-Mobarhan M, Parizadeh SM, Abasalti Z, Yaghoobi Z, et al. Natural honey and cardiovascular risk factors; effects on blood glucose, cholesterol, triacylglycerole, CRP, and body weight compared with sucrose. Scientific World Journal 2008; 8: 463-469.

18. Yochum L, Kushi LH, Meyer K, Folsom AR. Dietary flavonoid intake and risk of cardiovascular disease in postmenopausal women. Am J Epidemiol 1999; 149: 943-949.

19. Alagwu EA, Okwara JE, Nneli RO, Osim EE. Effect of honey intake on serum cholesterol, triglycerides and lipoprotein levels in albino rats and potential benefits on risks of coronary heart disease. Niger J Physiol Sci 2011; 26: 161-165.

20. McKenney J. Niacin for dyslipidemia: considerations in product selection. Am J Health Syst Pharm 2003; 60: 995-1005.

21. Patti AM, Al-Rasadi K, Giglio RV, Nikolic D, Mannina C, Castellino G, et al. Natural approaches in metabolic syndrome management. Arch Med Sci 2018; 14: 422-441. 
22. Ramli NZ, Chin KY, Zarkasi KA, Ahmad F. A review on the protective effects of honey against metabolic syndrome. Nutrients 2018; 10: E1009.

23. Alemam H, Abugeela M, Lamami Y, Enattah N, Bashein A. Effect of honey and olive oil on serum cholesterol levels: A preliminary study. EPH - International. J Appl Sci (Thailand) 2019; 1: 770-777.

24. Al-Waili NS. Natural honey lowers plasma glucose, C-reactive protein, homocysteine, and blood lipids in healthy, diabetic, and hyperlipidemic subjects: comparison with dextrose and sucrose. J Med Food 2004; 7: 100-107.

25. Mazruei Arani N, Emam-Djomeh Z, Tavakolipour H, SharafatiChaleshtori R, Soleimani A, Asemi Z. The effects of probiotic honey consumption on metabolic status in patients with diabetic nephropathy: A randomized, double-blind, controlled trial. Probiotics Antimicrob Proteins 2019; 11: 1195-1201.

26. Bekkaye I, Azzoug S, Dahmoun K, Chentli F. Effects of natural honey intake on glycemic control and lipid profile in type 2 diabetes. J Nutr Sci \& Diet 2016; 2: 36-42.

27. Bhatti I, Inayat S, Uzair B, Menaa F, Bakhsh S, Khan H, et al. Effects of nigella sativa (Kalonji) and honey on lipid profile of hyper lipidemic smokers. Ind J Pharmaceut Educ Res 2016; 50 : 376-384.

28. Derakhshandeh-Rishehri SM, Heidari-Beni M, Feizi A, Askari GR, Entezari MH. Effect of honey vinegar syrup on blood sugar and lipid profile in healthy subjects. Int J Prev Med 2014; 5: 1608-1615.

29. Despland C, Walther B, Kast C, Campos V, Rey V, Stefanoni $\mathrm{N}$, et al. A randomized-controlled clinical trial of high fructose diets from either Robinia honey or free fructose and glucose in healthy normal weight males. Clin Nutr ESPEN 2017; 19: $16-22$.
30. Erejuwa OO, Aja DO, Uwaezuoke NI, Nwadike KI, Ezeokpo BC, Akpan JL, et al. Effects of honey supplementation on renal dysfunction and metabolic acidosis in rats with high-fat dietinduced chronic kidney disease. J Basic Clin Physiol Pharmacol 2020; May: /j/jbcpp.ahead-of-print/jbcpp-2019-0151/jbcpp2019-0151.xml.

31. Whitfield P, Parry-Strong A, Walsh E, Weatherall M, Krebs JD. The effect of a cinnamon-, chromium- and magnesiumformulated honey on glycaemic control, weight loss and lipid parameters in type 2 diabetes: an open-label cross-over randomised controlled trial. Eur J Nutr 2016; 55: 1123-1131.

32. Bahrami M, Ataie-Jafari A, Hosseini S, Foruzanfar MH, Rahmani M, Pajouhi M. Effects of natural honey consumption in diabetic patients: an 8-week randomized clinical trial. Int J Food Sci Nutr 2009; 60: 618-626.

33. Majid M, Younis MA, Naveed AK, Shah MU, Azeem Z, Tirmizi $\mathrm{SH}$. Effects of natural honey on blood glucose and lipid profile in young healthy Pakistani males. J Ayub Med Coll Abbottabad 2013; 25: 44-47.

34. Münstedt K, Hoffmann S, Hauenschild A, Bülte M, von Georgi R, Hackethal A. Effect of honey on serum cholesterol and lipid values. J Med Food 2009; 12: 624-628.

35. Rasad H, Entezari MH, Ghadiri E, Mahaki B, Pahlavani N. The effect of honey consumption compared with sucrose on lipid profile in young healthy subjects (randomized clinical trial). Clin Nutr ESPEN 2018; 26: 8-12.

36. Wan Ghazali WS, Mohamed M, Sulaiman SA, Aziz AA, Yusoff HM. Tualang honey supplementation improves oxidative stress status among chronic smokers. Toxicol Environ Chem 2015; 97: 1017-1024. 